\title{
Bank as a Stakeholder in the Financing of Renewable Energy Sources. Recommendations and Policy Implications for Poland
}

\author{
Karolina Daszyńska-Żygadło *, Krzysztof Jajuga and Justyna Zabawa (D) \\ Faculty of Economics and Finance, Wroclaw University of Economics and Business, 53-345 Wrocław, Poland; \\ krzysztof.jajuga@ue.wroc.pl (K.J.); justyna.zabawa@ue.wroc.pl (J.Z.) \\ * Correspondence: karolina.zygadlo@ue.wroc.pl
}

\section{check for} updates

Citation: Daszyńska-Żygadło, K.; Jajuga, K.; Zabawa, J. Bank as a Stakeholder in the Financing of Renewable Energy Sources.

Recommendations and Policy Implications for Poland. Energies 2021, 14, 6422. https://doi.org/ 10.3390/en14196422

Academic Editors: Andrzej Graczyk, Periklis Gogas and Alicja Małgorzata Graczyk

Received: 15 August 2021

Accepted: 2 October 2021

Published: 8 October 2021

Publisher's Note: MDPI stays neutral with regard to jurisdictional claims in published maps and institutional affiliations.

Copyright: (c) 2021 by the authors. Licensee MDPI, Basel, Switzerland. This article is an open access article distributed under the terms and conditions of the Creative Commons Attribution (CC BY) license (https:// creativecommons.org/licenses/by/ $4.0 /)$.

\begin{abstract}
The paper concerns the role of the banking sector in renewable energy financing in Poland The main goal of the paper is to provide recommendations for the banking sector in Poland, which can be used in the process of financing RES. The main methods used in the paper are the thorough analysis of the solutions used to finance RES in different countries and multivariate analysis of options presented on the ordinal scale. The first finding is the answer to the question of which financial instruments used by banks are the most effective in the financing of RES. It is based on the prepared ranking of different instruments used by banks in the process of renewable energy financing, by assessing the structure and value of required financing for renewable energy based on future scenarios. The second finding in the paper is the set of recommendations for the banking sector and policymakers as to financing renewable energy sources in Poland. The main conclusion is that renewable energy financing through the instruments available in the banking sector is efficient and is characterized by relatively low risk.
\end{abstract}

Keywords: renewable energy; banking sector; stakeholders analysis; financing instruments; risk analysis

\section{Introduction}

Renewable energy sources (RES) continuously play a more significant role in current economies in the EU countries as well as in the world. The need for energy and its related services to satisfy human, social and economic development, welfare, and health, is increasing. For that reason, returning to renewable energy sources to help mitigate climate change is an important approach that needs to be sustainable to meet energy demand for future generations in the world [1]. On the other hand, mitigation of global warming requires substantial investment in electricity generation from renewable sources [2].

Renewable energy production and consumption are becoming increasingly attractive alternatives due to the engaged financial resources, decreasing production costs, improved efficiency, and changing market conditions [3]. The importance of the problem is confirmed by the number of published scientific papers concerning RES (based on Scopus-179,247 papers as of April 13, 2021, and Web of Science-122,953 papers as of April 13, 2021).

The biggest share of renewable energy production seems to be the domain of highly developed countries due to their extended sources of funds for capital intense investments, which usually have long payback periods. Countries characterized by high GDP per capita are also more likely willing to conduct that type of investment due to the wealth of the society. Higher material status translates into higher needs, related for example to the need to take care of the environment. Data from Enerdata seems not to fully support that claim. RES usage leaders, as a percentage of the total energy generated, are Norway (over 97\%), New Zealand (over 83\%), or Canada (over 65\%), but also poorer countries such as Brazil (over $80 \%$ ), Colombia (over $75 \%$ ), or Venezuela (over 70\%) [4].

Although the advantages of using RES are indisputable, the researchers sometimes point to limitations and barriers e.g., of the household sector, concerning the implementation of renewable energy sources for certain countries or regions [3]. 
Luthra et al. (2015) [5], in their research study in India, classified the possible barriers of RES's development into seven dimensions: economic and financial, market, awareness and information, technical, ecological and geographical, cultural and behavioral, and political and government issues. Their study confirms the significance of financial issues for the implementation of RES. For that reason, the banking sector can play from year by year a more significant role in the process of financing renewable energy.

Other studies concerning RES show that RE solutions often face difficult economic, technical, institutional problems and barriers as well, e.g., poor financing arrangements, high technical risks, unhelpful regulations, and faulty market systems [6-9].

In our paper, we are focusing on the research problem of the role of the banking sector in RES financing in Poland. There are two reasons for this. First of all, Poland is the country which depends on coal in energy production the most of all the European countries. Therefore the change of the energy mix in favor of renewable energy will be very difficult. Second, the financial system in Poland is a typical bank-oriented system, which means that banks play a significant role in the process of financing renewable energy in many countries. These financial institutions are one of the major sources of finance both for SMEs/companies (corporate debt on-balance-sheet financing) as well as for project finance [10]. From 2002 to 2012 corporate lending to companies operating in the clean energy sphere in Europe averaged at around 3 USD bn with a potential of more than 38 USD bn [11].

According to Martin and Rice [6], we used in our research stakeholder theory to examine the targets, policies, and actions identified by firms and stakeholder organizations in the RE industry sector. Our motivation to study the field of requirements for financing renewable energy investments comes from the aforementioned facts. We take the perspective of banks as the key stakeholders in the process. We focus on the Polish contextual environment as even though the problem is globally recognized and universal the recommendations for the banking sector have to include regional specificity.

One of the goals of our study is to emphasize the role of the banks in the transition to a sustainable economy. The main aim of our research is to provide recommendations for the banking sector in Poland, which can be used in the process of financing RES.

We contribute to the science by providing an assessment of financial instruments used by banks in the process of renewable energy financing, by concluding concerning structure and value of required financing for renewable energy based on future scenarios, and finally by providing policy recommendations for the banking sector in Poland. The remaining part of the paper is structured in the following way. In the next part, we provide a literature review and theoretical background. We analyze scientific papers related to the involvement of the banking industry in financing of RES, as well as regulations and EU goals concerning RES, financing of renewable energy in the world, and financing of RES by banks. Based on the literature review we stated two main research questions in the paper. The third part consists of the description of materials and methods. A key role in our paper is played by the qualitative analysis of literature and regulations concerning the role of the banking sector in financing renewable energy. In the fourth part of the paper, we provide results of the analysis of historical data on investment in renewable energy, including relative measures, and we present simulations on the development of that market in the future in correspondence to the analysis of required sources of funding. Based on our results, in the fifth part, we conclude, presenting stakeholders' analysis and analysis of solutions related to the financing of RES by banks in different countries to derive recommendations for the banking sector in Poland.

\section{Literature Review and Theoretical Background}

\subsection{Analysis of Renewable Energy Market in Poland in Comparison with EU Countries}

The analysis of the share of RES in the country may be carried out concerning several variables:

- RES share in electricity production (in the energy mix) for the year,

- RES share in final electricity consumption for the year, 
- year-on-year growth rate for the two above-mentioned variables,

- $\quad$ share of RES expenditure in GDP for the year.

Analyzing the EU countries with the highest share of RES in electricity production (over 30\%), the set presented in Table 1 was obtained. The table also shows the share of renewable energy sources in final energy consumption, expenditure on renewable energy sources to GDP, and GDP per capita.

Table 1. EU countries with the highest RES share in electricity production and Poland in 2018.

\begin{tabular}{|c|c|c|c|c|c|}
\hline & Country & $\begin{array}{l}\text { RES Share in Electricity } \\
\text { Production }(\%)\end{array}$ & $\begin{array}{l}\text { RES Share in Final Electricity } \\
\text { Consumption for the Year }(\%)\end{array}$ & $\begin{array}{c}\text { Investment } \\
\text { Expenditure/GDP\% }\end{array}$ & $\begin{array}{l}\text { GDP per Capita } \\
\text { (USD) }\end{array}$ \\
\hline 1 & Norway & 97.88 & 72.75 & 0.368905 & 81,695 \\
\hline 2 & Denmark & 68.30 & 35.71 & 0.482870 & 60,692 \\
\hline 3 & Sweden & 55.27 & 54.65 & 0.809246 & 53,873 \\
\hline 4 & Portugal & 52.18 & 30.32 & $\mathrm{n} / \mathrm{a}$ & 23,186 \\
\hline 5 & Finland & 45.10 & 41.16 & 0.364680 & 49,845 \\
\hline 6 & Romania & 41.27 & 23.88 & $\mathrm{n} / \mathrm{a}$ & 12,285 \\
\hline 7 & Italy & 39.87 & 17.78 & 0.096346 & 34,260 \\
\hline 8 & Spain & 38.62 & 17.45 & 0.525382 & 30,697 \\
\hline 9 & Germany & 36.00 & 16.48 & 0.159440 & 48,264 \\
\hline 10 & Great Britain & 33.98 & 11.02 & 0.311082 & 42,558 \\
\hline 11 & Poland & 12.70 & 11.84 & 0.90000 (Estimates) & 15,431 \\
\hline
\end{tabular}

Source: own calculations based on: Eurostat, International Monetary Fund (IMF), Enerdata Energy Statistical Yearbook.

In some countries, large disproportions can be observed between the share of renewable energy sources in electricity production and the share of renewable energy sources in final energy consumption. RES financing solutions applied in the group of countries outside the EU, but with a high RES share of electricity production for 2018 (i.e., New Zealand, Australia, the United States, and China) could prove helpful insights for the Polish banking sector.

There is also an interesting aspect connected with the evolution of the renewable energy integration. When we analyze some countries, e.g., France, Czech Republic, Germany, and Romania, we can observe that the level of this integration in the years 2014-2018 is different. RES share in 2018 reaches 21.2\% in France, increasing by 2.91\% since 2014 [12]. It is also remarked that the share structure for energy sources in Germany is somewhat similar to the Romanian one. A steady annual increase of RES can be noticed, rising by $11.2 \%$ during the considered time horizon, up to $40.6 \%$ in 2018 . In the Czech Republic, RES share in the total power production balance shows a reduction, declining in 2018 to a value almost halved (6.17\%) compared to the one achieved in 2015.

Among the currently used instruments for financing and supporting investments in renewable energy sources in Poland, the following can be mentioned:

- a subsidy system for investments in renewable energy sources (funds granted at the central and local level, EU funds, funds from the National Fund for Environmental Protection and Water Management (NFOŚiGW) and its provincial branches),

- $\quad$ large investment loans (bank consortia) for the construction of power plants producing electricity from RES,

- preferential credits and loans granted by the banking sector,

- project finance,

- public-private partnership (PPP),

- leasing,

- green bonds, 
- issue of shares,

- feed-in-tariff (TiF) and feed-in-premium (FiP),

- auction system,

- tradable green certificates system,

- tax benefits:

- for individual clients-beneficiaries of subsidies: exemption from individual income tax for subsidies and thermo modernization relief,

- $\quad$ for RES energy producers-exemption from VAT and excise duty.

Currently (as of June 2021), there are several support programs for investments in renewable energy. Additionally, preferential credits and loans offered by the banking sector in Poland and international financial institutions are dedicated to these investments.

These instruments are addressed to specific groups of beneficiaries, such as households, entrepreneurs (including mainly the SME sector), and other entities, such as local governments, housing communities, and cooperatives. A special role in the financing of this type of investment is played by the National Fund for Environmental Protection and Water Management (NFOŚiGW) and its provincial branches. In connection with the above conditions, several classifications regarding the sources of financing of RES in Poland can be introduced:

(1) sources of NFOŚiGW, including [13]:

- domestic sources, programs like: Mój Prąd, Kawka, Kawka Plus, Czyste Powietrze, Agroenergia,

- $\quad$ sources from EU, e.g., Operational Program Infrastructure and Environment 2014-2020, LIFE Program,

- Norway grants and grants from the European Economic Area (EEA),

- green investment scheme,

(2) type of financing source:

- private sources: funds granted in the form of preferential credits and loans for pro-ecological investments, mainly by the banking sector,

- public sources,

- funds from foreign sources e.g., Program PolSEFF2-Polish Sustainable Energy Financing Facility,

(3) type of the beneficiary:

- individual clients,

- enterprises, mainly SMEs,

- local governments,

- others, e.g., farmers, housing communities.

The largest photovoltaic project in Poland is currently implemented by the Energy and Infrastructure SME Fund in cooperation with DNB Bank Polska SA and the European Investment Bank (EIB). A loan in the total amount of PLN 164 million was taken out for the investment.

Along with the development of renewable energy sources, there will be a necessity to invest in energy infrastructure. It is expected that project finance will be the more commonly used technique of financing in Poland. This method of investments financing is often used in the world. A particular increase may be visible in the application of publicprivate partnerships (PPP), where public investments are carried out by the private sector. In most cases, it will be applied by energy companies.

There are examples of green bonds issues in Poland. The first issuer was the State Treasury, which placed five-year green bonds in euros on international markets at the end of 2016. It was the first issue of green treasury bonds in the world. The first issuer of green bonds in the private sector in Poland was BZ WBK SA (currently Santander Bank Polska SA). In May 2017, the bank issued its bonds worth EUR 137 million. In 2019, ING Bank Hipoteczny SA issued 5-year green mortgage bonds worth PLN 400 million. The funds 
obtained from the issue of covered green bonds will be used to finance energy-saving "green" mortgages.

In the years 2013-2019, the total value of investments in RES in Poland amounted to PLN 48 billion, and for 2019 it was close to PLN 15 billion. As can be seen in the diagram (Figure 1), commercial banks are the main source of RES financing. In each of the analyzed technologies, the banking sector is responsible for over $50 \%$ of the investment value. In 2019 , the involvement of the banking sector in financing investments in renewable energy sources amounted to PLN 10.5 billion.

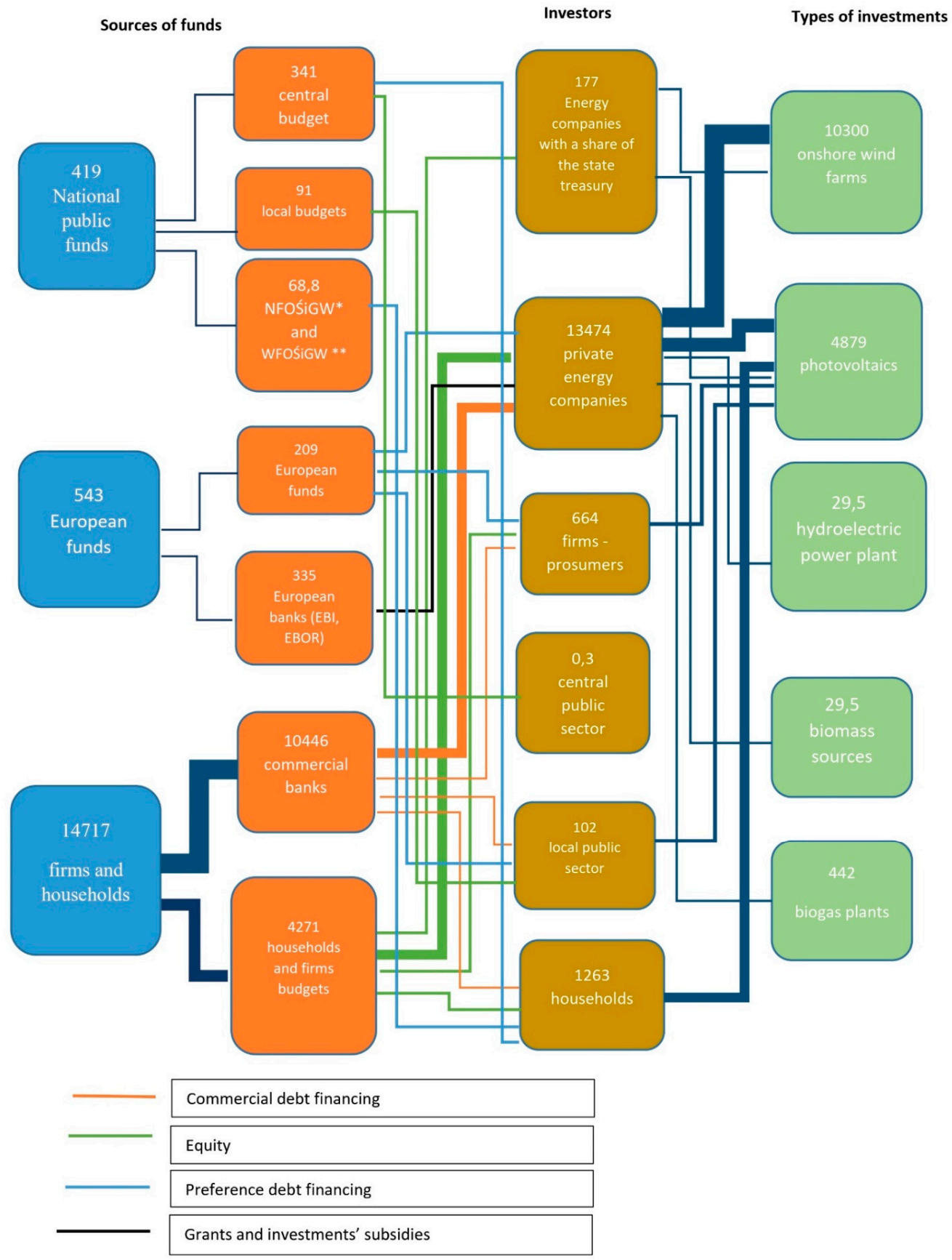

Figure 1. Graphic representation of low-carbon investments in power engineering in 2019 (in $\mathrm{mn}$ PLN). * National Fund for Environmental Protection and Water Management. ${ }^{* *}$ Regional Fund for Environmental Protection and Water Management. Source: own elaboration based on report for ZBP and "Alternating current. panorama of low-emission investments in the energy sector", WiseEuropa-Foundation Warsaw Institute of Economic and European Studies, Warsaw 2020. 


\subsection{Regulations and EU Goals Concerning RES}

International and national policies ought to promote the development of the renewable energy sources sector $[14,15]$. The strategic documents of the European Union (EU) indicate the need for the intensification of this process across all EU member states [16].

During the talks of the Climate Summit of the European Union in March 2007, some measures to mitigate the climate changes up to 2020, were introduced. The proposals were related to climate and energy, called $3 \times 20$.

The goals were assumed by the governments of EU countries in 2007, and two years later, in 2009, the particular regulations were introduced. Reducing carbon dioxide emissions is one of the main practices that can be used to achieve the objectives set by energy policies [17].

These are also the main goals of the strategy: "Europe 2020-A strategy for smart, sustainable and inclusive growth" [18]. It is worth mentioning that these goals can be different for the different countries depending on their starting point as to renewable energy production and its capacity to increase-from 10\% in Malta to $49 \%$ in Sweden. For Poland this goal was set to $15 \%$, for Germany it was $18 \%$.

The continuation of the strategy "Europe 2020-A strategy for smart, sustainable and inclusive growth" is the European Green Deal. This is the set of the actions for the sustainable economy of the European Union and, as a consequence, to transform Europe to be the first continent neutral concerning climate [19].

These actions will be performed by the transformation of the challenges related to climate and environment to the new opportunities in the policy. European Green Deal emphasizes the fairness and the social inclusion of the transformation.

According to the strategy European Union will provide financial support and technical help for people, enterprises, and regions that are the most prone to the consequences of the transformation to the sustainable economy. To achieve this goal the mechanism of fair transformation will be used to provide for some regions 100 billion euros in the period 2021-2027.

One of the areas in the European Green Deal is "Clean Energy" [20]. The key role for the achievement of the goals presented in the European Green Deal is the decrease of the emission of the energy system of the European Union.

It should be added that Poland and other seven countries (Lithuania, Latvia, Estonia, Austria, Greece, Spain, and Luxembourg) signed the letter to the European Commission on the new industrial strategy for Europe and the use of renewable energy after the COVID-19 pandemic. The main postulates presented in this letter are:

- The appreciation of the technology used in the production and storage of renewable sources of energy as the strategic elements of the supply chain;

- Investing over the next 30 years more than 2 billion euros in the wind and solar energy;

- Placement of renewable energy production in Europe.

According to these postulates, the role of local producers in the supply chain should be strengthened. To facilitate this, the mechanism IPCEI (Important Projects of Common European Interest) related to renewable energy, will be launched.

From the point of view of the development of RES in Poland, the important document is "Energy policy of Poland until 2040" [21], proposed by the Ministry of Energy. This document can be treated as the response to the challenges for the Polish energy sector. As the measure of the realization of this strategy, the contribution of RES to final energy use is $21 \%$ in 2030 . The key role should be played by the development of photovoltaics (from 2022) and offshore wind farms (the first one will start after 2025).

These strategic goals and assumptions both on the European and Polish levels provide a framework for our analysis and results of future scenarios.

\subsection{Financing of Renewable Energy in the World}

The banking sector is facing challenges related to the development of the renewable energy sector. This comes from the climate changes as well from the need to create an 
ecological financing strategy taking into account the increasing participation of renewable energy in the energy mix, both at the domestic and the international level.

The analysts estimate that about 13.3 billion USD will be invested in new production capacities; out of this amount, 10 billion USD (about 77\%) will be invested in the renewable energy sector (based on IRENA data). In particular, investments in the wind energy sector will amount to 5.3 billion USD and in the solar energy sector will amount to 4.2 billion USD. All energy investments will amount to $15145 \mathrm{GW}$ of new power stations in the period 2019-2050, and $80 \%$ of them should be zero-emission power stations. The participation of solar and wind energy in the world energy mix is constantly increasing. For Europe, it will increase from $8 \%$ in 2012 to $80 \%$ in 2050 [22].

Due to the importance of climate change and the depletion of conventional sources, actions concerning RES are supported institutionally. Support programs for various undertakings fulfilling the postulates of a low-carbon economy are implemented at the level of the European Union, individual member states, and local self-government units [23].

It proves that financing ecology investments, including renewable energy, is of key importance at both domestic and international levels.

The data provided by IRENA indicate that the countries with the largest investments in this area are made in the following regions: China, United States, Europe, Asia, and Oceania. A small decrease was observed in the years 2017-2018, due to China.

\subsection{Financing RES by Banks}

In our study, we analyzed papers concerning the financing issues of renewable energy by banks, based on the Scopus Database. We focused on the articles published from 2015 until now (May 2021). In the study, we focused on three keywords: "renewable energy", "financing", and "bank". In the Scopus for this period, we found 39 articles concerning our research area.

Many papers refer to the financing of renewable energy by the banking industry in large economies like Germany and UK [24-26].

Several papers represent the study field of RES financing by banks in developing countries, especially in China [24,27-30], BRICS Countries [31-34] and India, Philippines, Brazil, and other South-East Asian countries [35-38].

Based on the literature research we can point to cooperation between governments and green-oriented and green investment banks, which can lead to green investments banks supporting the green revolution in many countries. Government can play an important role in adopting a more open trade policy, providing a more friendly business environment for investors, encouraging innovation by establishing a green investment bank, reducing tax on low-carbon energy investment, and stimulating green investment in financial markets [39].

Other researchers show, on the example of Australia, the UK, and Germany, that aside from capital provision and de-risking, SIBs (state investment banks) take a much broader role in catalyzing private investments into low-carbon investments, including enabling financial sector learning, creating a trust for projects and taking a first or early mover role to help projects gain a track record [25]. In this way, these banks fulfill a financing gap in renewable energy. Geddes et al. [25] point in their paper that there is a significant "financing gap" for the low-carbon energy projects required to reduce global $\mathrm{CO}_{2}$ emissions to target levels and many are concerned that investments for the large-scale diffusion of renewables will not materialize fast enough.

These findings are confirmed by Niczyporuk and Urpelainen [29] in their paper concerning financing RES in China. A large investment gap prevails, particularly in developing economies with underdeveloped domestic capital markets and weak institutions in China. Multilateral development banks with softer budget constraints and longer investment horizons can play an important role in filling this gap [29].

Each of the analyzed papers takes a regional or local perspective, some conclusions might be generalized for other countries, but the inclusion of individual specificity plays a 
key role in deriving recommendations. That conclusion justifies our approach dedicated to Polish specificity.

There is a wide range of innovative tools related to sustainability (eco-design, procedural, organizational, etc.) and they require significant investments. Companies often fail to implement innovative eco-processes through self-financing; for that reason, the lenders and banks may be involved [40]. In many cases, large-scale projects, such as energy upgrading of the building sector in Europe, are funded by financial institutions such as the European Investment Bank and other funding institutions [41]. The European Bank for Reconstruction and Development-EBRD, which takes part in the processes of financing in $\mathrm{RE}$ technology is a good representation of that matter.

Banks can show their engagement in environmental protection, especially in the financing of RES, by application of environmental accounting [42,43]. The results of Masud et al. [44] based on the analysis of 20 banks listed on the Dhaka Stock Exchange in Bangladesh for the period 2010 to 2014 confirm that. Their results indicate that the examined banks significantly disclosed environmental information for 12 categories. The study found that banks revealed the most environmental information in the categories of green banking and renewable energy, and the least in terms of environmental recognition and waste management.

Based on the above literature findings, we can state that banks play a significant role in financing renewable energy investments. They facilitate mobilization of capital, formulate consortia, and take part in large-scale projects often through project finance fulfilling the financing gap for renewable energy. On top of that, a notion comes out ahead that banks recognize the lending activity in the scope of renewable energy as part of their sustainability or environmental protection strategy.

In the studied literature selected in the Scopus database with our keywords research an issue of financial instruments used to fund RES projects prevails. Geddes et al. [25] point in their paper to the following financial instruments in three state investment banks (SIBs):

- Clean Energy Finance Corporation (CEFC) in Australia: debt (market rate, long-term), debt (concessional, limited to AUD 300 million (USD 237 million) in NPV terms per year, equity (introduced after interviews), securitization/aggregation products, guarantees (restricted to $5 \%$ uncommitted balance),

- Green Investment Bank (GIB) in the UK: debt (market rate, long-term), debt (subordinated, mezzanine), equity (incl. bridging equity loans), securitization/aggregation products,

- Kreditanstalt fuer Wiederaufbau (KfW) in Germany: debt (concessional, long-term), debt (market rate, long-term, for offshore wind, energy transition-related R\&D, SME and large corporate projects), equity (limited amount), and grants.

Other authors like Garcia-Bernabeu et al. [45] underline the significance of project finance as a recent method widely used in RE projects. In these projects lenders usually manage two types of information regarding (i) the financial performance of the project; (ii) non-financial information about risk provided by technical and legal reports. According to Zhang [28], a bank loan provided by Chinese policy banks such as the China Development Bank (CDB) and the commercial banks is currently the main financing mechanism for DSPV (distributed solar PV) power projects in China. Lowitzsch [46] presented in his paper another solution for RES financing: CSOPs-Consumer Stock Ownership Plans. He has shown that CSOPs-designed to facilitate scalable investments in utilities-facilitate co-investments by municipalities, SMEs, plant engineers, or energy suppliers. Being a low-threshold financing method, they enable individuals, in particular low-income households, to invest in renewable projects. Employing one bank loan instead of many microloans, CSOPs reduce transaction costs and enable consumers to acquire productive capital, providing them with an additional source of income [46].

McInerney and Bunn [47] list other financial products for the RE sector: green bonds, loans from green investment banks, securitizations and crowdfunding. They are showing substantial potential but also difficulties with these instruments. Green bonds face certifi- 
cation and trust issues, green investment banks require a mature financial sector to work alongside government policy initiatives, yield cost needs tax benefits, and crowdfunding has community appeal but may remain local in scale.

Based on these literature findings we are posing the first research question:

Q1: Which financial instruments used by banks are the most effective in the financing of RES?

The third cluster of research papers is dedicated to the recommendations for the banking sector.

Some researchers underline the significance of policy support from governments [39]. This kind of support from governments is needed to promote private finance into the RE sector by encouraging it to come up with innovative ways, such as the establishment of the green investment bank. The two case studies show that public financial institutions can play a leading role in reducing the cost of CSP (concentrated solar power). Support of public budgets by providing concessional loans in countries where public and/or private finance would be too expensive, and extending maturities where commercial investors are present but poorly suited for project finance [48] is another recommendation. The authors have shown that, combined with a competitive tariff setting mechanism (tenders and auctions), public financial support can also be a cost-effective tool to engage private investors in CSP.

Many banks now use the Equator Principles (EPs) as a framework for assessing environmental and social risks into project finance, but few integrate sustainability into more widespread credit products [49]. Sustainability is unfortunately still not a deciding factor in risk models by commercial banks. The Sustainable Financing Model for Renewable Energy presented by Sukirman would complement regular credit rating models by yielding qualitative and quantitative information that would lead to improved decision-making [49]. This means increased interest rates or denial of credit by the bank, even if the company is otherwise creditworthy. Conversely, companies with high sustainability ratings could get preferred treatment, either in terms of costs or access to capital.

The practitioners and the researchers try to study how sustainability criteria can be integrated into risk management models and lending practices. Financing of RES is easier to mobilize when pre-existing and strong relationships between lenders and borrowers are leveraged [24]. Institutional investors and lenders such as pension funds and banks, in particular, are reluctant to invest in renewable energy or grid infrastructure because of expected (policy) discontinuities [11]. Based on these findings we developed our second research question:

Q2: What recommendations for the banking sector in Poland can strengthen the importance of these institutions in financing renewable energy?

The last part of our literature review has shown that there is a great interest in the riskrelated issues when RES projects are being analyzed. Financial actors vary considerably in the composition of their investment portfolio, creating directions towards particular technologies of RES. Generally, public financial actors invest in portfolios with higher risk technologies. The investment risk depends on the kind of RES [50]. For that reason, the authors distinguished 11 different financial actors (e.g., private banks, public banks, and utilities) and 11 types of RE technologies that are invested in (e.g., different kinds of power generation from solar radiation, wind, or biomass).

On the other hand, the study of Safarzyńska and van den Bergh [51] shows that investing too much and too fast in renewable energy increases the chances of cascades of bank failures. In particular, increasing shares of RE decreases the interbank connectivity by causing the concentration of large loans to energy utilities in few banks.

The analysis of Niczyporuk and Urpelainen [29] shows that projects located in countries that are politically stable but have higher credit risk and corruption levels like China are more likely to receive national energy finance. Governance risk and autocratic regime type do not affect the decisions of the Chinese banks.

Matthäus and Mehling [2] propose the new solutions connected with the level of investment risk in RES. Their "Multilateral Guarantee Mechanism" can reduce the risk 
premia of renewable energy investments through risk pooling and increased market efficiency. Policymakers could establish this mechanism by scaling up existing international risk guarantee initiatives.

Based on these considerations we developed our third research question:

Q3: What types of risk should be analyzed by banks when they consider investments in RES projects?

We recognize that risk aspects are highly relevant in the analysis of financing opportunities for renewable energy investments from the bank's perspective; that is why we dedicate space to it in our empirical study and we include recommendations concerning risk.

\section{Materials and Methods}

Our work comes mainly under the category of a policy paper. Therefore, we focus on qualitative analysis and provide conclusions based on studied materials.

The materials that we used for the research encompass:

- $\quad$ scientific papers-for literature review and discussion about the role of the banks in the financing of renewable energy projects in different parts of the world, to discuss the selection of financial instruments used by banks and to find out the risk factors related to RES investments;

- $\quad$ energy sector reports and reports of future studies agencies and think tanks such as Wise Europa and research foundation of The Polish Bank Association-as a background for our recommendations for the banking sector in Poland and deriving simulations and scenarios of the future of the energy sector in Poland and its sources of funding;

- statistical data from IMF and Eurostat-to retrieve data about GDP and investments in RES and

- Enerdata materials for detailed analysis of renewable energy shares in energy production.

Based on the analysis of the data and materials using expert methods of assessments we provide recommendations for the Polish banking sector in the following manner. First, we derive two future scenarios until 2035 for the Polish renewable energy market and we create a simulation of required financing concerning the proposed structure of types of funding.

Second, using expert assessment and scale from 1 to 3 (where 1 stands for least favorable and 3 stands for most favorable) we critically evaluate various available financial instruments from the perspective of a bank in the following criteria: risk, the value of the investment, rate of return, availability, reputation, and support for energy transformation. Third, we provide recommendations for the Polish banking sector based on:

- literature review findings;

- policy recommendations of European Union;

- results of scenarios of the future and simulation for investments in the renewable energy and sources of financing;

- analysis of strategies and instruments used in other countries; and

- risk analysis.

\section{Results}

To answer our research questions we structured our results into two parts.

The first part presents the future scenarios developed for the renewable energy market in Poland including the perspective of the banking sector. The investment requirements and structure of sources of financing are simulated for each scenario.

The second part of our findings provides an assessment of investment risk in renewable energy by banks in Poland.

We finalize the results with an assessment of particular financing instruments from the perspective of banks in Poland based on the future scenarios, simulation, risk analysis, and experts' opinions. 


\subsection{Bank as a Main Source of Capital in Financing Renewable Energy}

To estimate the gap between the current level of low-carbon energy technologies investments and the investment needs in the horizon of the year 2035, two scenarios were analyzed:

- Scenario I: based on National Plan for Energy and Climate approved at the end of 2019;

- Scenario II: based on the version of the National Plan for Energy and Climate that includes the shutdown of coal-fired power plants until 2035 and that assumes accelerated investment in RE (additional onshore wind farms with a capacity of $13 \mathrm{GW}$ and photovoltaic farms with a capacity of $11 \mathrm{GW}$ ) supplemented with gas power plants and gas heat and power plants (total power of $16 \mathrm{GW}$ until 2035).

Scenario I assumes focusing on the development of offshore wind farms and gradual increase of photovoltaic capacity, with a simultaneous acceleration of investments in biogas plants, sources based on biomass, and - to a smaller extent-in hydroelectric power plants [52]. Implementation of the scenario I would mean a decrease of annual investment expenditures for renewable energy almost by half in comparison with the results of 2019 . As a result, investment in RE in the years 2021-2035 would be only $17 \%$ higher than the average for the years 2013-2019.

Therefore, the scenario I of the development of renewable sources with a focus on biomass and biogas is different from market expectations and possibilities. These two sources were not drawing much attention from investors and the financial market until now, while the scenario underestimates financing opportunities of renewable energy in Poland based on national sources (equity and debt) and European (grants and debt).

Scenario II assumes accelerated shutdown of coal-fired power plants and requires additional development of onshore wind farms and photovoltaics. This foreseen development is fully comparable with the scale of investment from 2019. The forecasted structure of investment expenditures in the years 2021-2035 in this scenario is analogical to the structure of projects started in 2019. The key difference is the diversification of investment in offshore and onshore wind farms. In this scenario, the required investment in the years 2021-2035 would equal PLN 10 bn per year for wind energy, where offshore wind farms would constitute $50 \%$ of that amount.

Data collected within this research iwith respect to potential sources of funds for RE projects allow us to simulate the future structure of financing of RES. If the average structure of financing of analyzed technologies from 2013-2019 is maintained, we can estimate it for both scenarios.

The scenario I simulation shows that own funds mobilized per year by investors (including households and prosumers) should be lower by PLN 600 million than the amount invested in 2019. Funds required from the financial sector would be slightly larger (PLN 5 million) than it was on average in the years 2013-2019 (PLN 4.2 million), but only $50 \%$ of the amount financed in 2019. By contrast, in the simulation dedicated to scenario II, yearly requirements for commercial loans would be lower (PLN 9.6 million) than in 2019 (PLN 10.4 million). Details of both simulated scenarios in comparison with historical data are depicted in Figure 2.

In the next step of our analysis, we provide estimates of the scale of investments in the banking sector in both scenarios. With those, we simulate and assess the effects of planned policies. Both simulations are prepared based on forecasted shares of renewable energy sources in the "Energy-climate policy scenario" for the years 2025 and 2035 [53]. The data: for the production of electricity from RES (in TWh) and investments in renewable energy (in mln euro) were taken from reports $[52,53]$. The annual value $(\mathrm{GWh})$ in Table 2 was calculated by dividing the value within 15 years (TWh) by 15 and multiplied by 1000 . Then, all annual values (in GWh) were added. Based on this, share in \% of kind of RES was calculated as a part of the total value. Engagement of commercial banks in scenario 1 is 5 million PLN and for scenario II: 9.6 million PLN. Shares in investments were calculated according to shares in the production of RES. A similar method was used in Table 3. Results 
in Tables 2 and 3. present the estimated scale of the banking sector investment that allows reaching planned energy and climate goals.

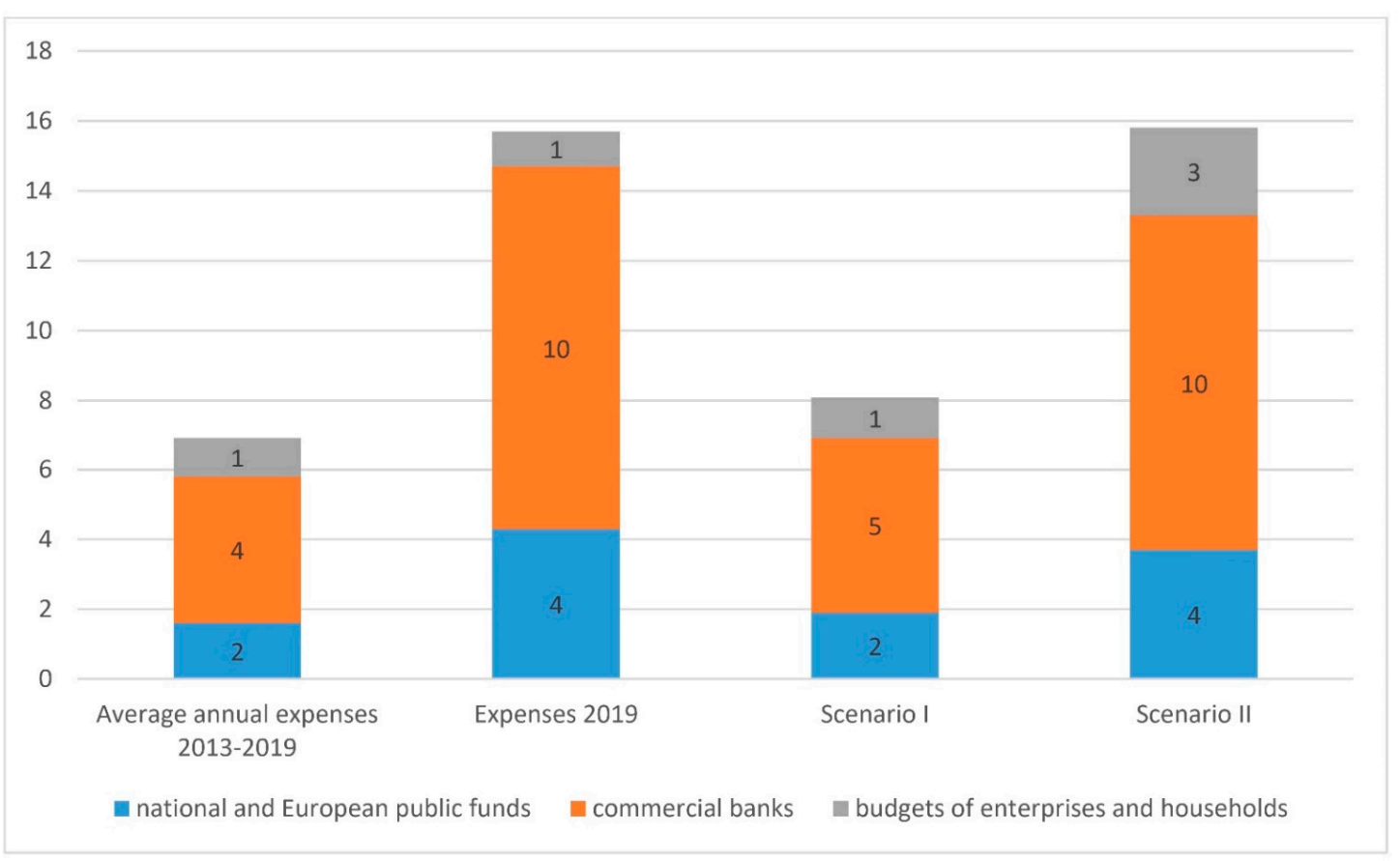

Figure 2. Average annual expenses on investment in renewable energy sources according to the source of financinghistorical data and forecast until 2035 (in bn PLN). Scheme 2020, and Jajuga K., Zabawa J., Daszyńska-Żygadło K., Report "Financing investments in renewable energy by Polish banks", 2020, The Polish Bank Association, Programu AnalitycznoBadawczego Fundacji Warszawski Instytut Bankowości, SYGN. WIB PAB 20/2020.

Table 2. The yearly average value of the investment in RE in respect to energy production to 2035 for a scenario I and II.

\begin{tabular}{ccccccccc}
\hline & $\begin{array}{c}\text { Until 2025 } \\
\text { (TWh) }\end{array}$ & $\begin{array}{c}\text { Until 2030 } \\
\text { (TWh) }\end{array}$ & $\begin{array}{c}\text { Until 2035 } \\
\text { (TWh) }\end{array}$ & $\begin{array}{c}\text { Within 15 Years } \\
\text { (TWh) }\end{array}$ & $\begin{array}{c}\text { Annual } \\
\text { (GWh) }\end{array}$ & $\begin{array}{c}\text { Share in } \\
\text { \% }\end{array}$ & $\begin{array}{c}\text { Scenario I } \\
\text { (PLN) }\end{array}$ & $\begin{array}{c}\text { Scenario II } \\
\text { (PLN) }\end{array}$ \\
\hline Hydro energy & 2.9 & 3 & 3 & 8.9 & 593.33 & 4.79 & $239,376,009$ & $459,601,937$ \\
\hline Biomass & 9.7 & 11.6 & 11.4 & 32.7 & 2180.00 & 17.59 & $879,505,110$ & $1,688,649,812$ \\
\hline Biogas & 2.7 & 3.9 & 5 & 11.6 & 773.33 & 6.24 & $311,995,697$ & $599,031,737$ \\
\hline Wind onshore & 23.7 & 23.8 & 24.2 & 71.7 & 4780.00 & 38.57 & $1,928,456,159$ & $3,702,635,826$ \\
\hline Wind offshore & 2.7 & 14.5 & 21.7 & 38.9 & 2593.33 & 20.93 & $1,046,261,431$ & $2,008,821,947$ \\
\hline Solar energy & 4.5 & 6.8 & 10.8 & 22.1 & 1473.33 & 11.89 & $594,405,594$ & $1,141,258,741$ \\
\hline Total & $\mathbf{4 6 . 2}$ & $\mathbf{6 3 . 6}$ & $\mathbf{7 6 . 1}$ & $\mathbf{1 8 5 . 9 0}$ & $\mathbf{1 2 , 3 9 3 . 3 3}$ & $\mathbf{1 0 0 . 0 0}$ & $\mathbf{5 , 0 0 0 , 0 0 0 , 0 0 0}$ & $\mathbf{9 , 6 0 0 , 0 0 0 , 0 0 0}$ \\
\hline & & & \multicolumn{2}{c}{ Source: own calculation based on [52,53]. } & &
\end{tabular}

Table 3. Yearly average value of the investment in RE in respect to investment expenditures until 2035. for a scenario I and II.

\begin{tabular}{|c|c|c|c|c|c|c|c|c|}
\hline & $\begin{array}{l}\text { Until } 2025 \\
\text { (Million } \\
\text { EUR) }\end{array}$ & $\begin{array}{l}\text { Until } 2030 \\
\text { (Million } \\
\text { EUR) }\end{array}$ & $\begin{array}{l}\text { Until } 2035 \\
\text { (Million } \\
\text { EUR) }\end{array}$ & $\begin{array}{l}\text { Within } 15 \text { Years } \\
\text { (Million EUR) }\end{array}$ & $\begin{array}{c}\text { Annual } \\
\text { (Million } \\
\text { EUR) }\end{array}$ & $\begin{array}{l}\text { Shares } \\
\text { in } \%\end{array}$ & $\begin{array}{l}\text { Scenario I } \\
\text { (PLN) }\end{array}$ & $\begin{array}{l}\text { Scenario II } \\
\text { (PLN) }\end{array}$ \\
\hline Hydro energy & 317 & 120 & 120 & 557 & 37 & 2.06 & $103,102,325$ & $197,956,464$ \\
\hline Wind energy & 1842 & 7467 & 5504 & 14,813 & 988 & 54.84 & $2,741,929,513$ & $5,264,504,665$ \\
\hline Solar energy & 2156 & 1659 & 2819 & 6634 & 442 & 24.56 & $1,227,972,753$ & $2,357,707,685$ \\
\hline Biomass & 1318 & 1109 & 93 & 2520 & 168 & 9.33 & $466,459,351$ & $895,601,955$ \\
\hline Biogas & 786 & 837 & 865 & 2488 & 166 & 9.21 & $460,536,058$ & $884,229,231$ \\
\hline Total & 6419 & 11,192 & 9401 & 27,012 & 1801 & 100 & $5,000,000,000$ & $9,600,000,000$ \\
\hline
\end{tabular}


Analysis of the values of investments in RE allows for the additional conclusion that there is a significant decrease in costs of offshore wind farms; according to the data for 2018, the price was equal to 2.5 million EUR/MW while in 2015 it cost approximately 4.5 million EUR/MW.

In 2021, in the Polish part of the Baltic Sea, there are eight advanced projects of offshore farms, for two of them („Bałtyk Środkowy III” of Polenergia and Norwegian Equinor and "Baltica 3 " of PGE) grid connection agreements were signed. They both have a capacity of 2.2 GW.

\subsection{The Assessment of Investment Risk in Renewable Energy by Banks in Poland}

The bank is the key player, as far as financing renewable energy investments are considered. Bank can take part in this process in three different roles:

- Bank as an issuer of debt instrument, as straight bonds or green bonds, the capital acquired through this issue is used to provide loans to finance renewable energy investments;

- $\quad$ Bank as an investor on the debt market, in such instruments like bonds (including green bonds), loans, also in project-finance and public-private partnerships;

- $\quad$ Bank as an intermediary (underwriter) of the issue.

Now we present the main types of risk, which are borne by the bank, being a very important player on the market of renewable energy investments. It is particularly important in the countries, where the bank is the main supplier of the capital, for example in Poland.

We understand risk in the negative concept, as downside risk.

\subsubsection{Bank as an Issuer of Debt Instrument}

In this case, the main risks are standard risks of the debt instrument issuer, namely:

- $\quad$ risk of nonplacement of the issue;

- $\quad$ interest rate risk.

The risk of nonplacement of the issue is rather small. The main explanation of this is the fact that issuing debt instruments is the standard operation conducted by the bank. Before deciding about an issue, the bank conducts a professional analysis of the profitability, in which the parameters of the bond are determined (maturity, coupon rate, frequency of payments). There is, however, a small chance, that after deciding about the issue but before selling the issue on the market, the situation on the market will change to the disadvantage of the issuer. This situation is not a very likely one.

Interest rate risk is reflected in two cases:

- $\quad$ fixed interest bond;

- floating interest bond.

For fixed interest bonds the negative effect of bond issuer risk occurs when the interest rates on the financial market are falling. This increases the market value of debt of the issuer-coupon payments are relatively high given market interest rates. The issuer can manage this risk by issuing a callable bond, which gives the issuer the right to redeem the bond before maturity. This right is then used when interest rates on the market are falling. However, the value of the callable bond is lower than the value of a similar straight bond, which results in less capital acquired through the issue.

For floating interest bonds the negative effect of bond issuer risk occurs when the reference rate which determines coupon payments (e.g., LIBOR) is raising. The issuer can manage this risk by using derivative instruments, for example, forward rate agreement, cap, or interest rate swap.

These considerations lead to the conclusion of low risk of the issuer of a debt instrument to finance loans used for renewable energy investments. 


\subsubsection{Bank as an Investor on the Debt Market}

In this case, the main risks are:

- credit risk;

- interest rate risk;

- $\quad$ prepayment risk.

Credit risk is the risk that the party which acquires capital from the bank can default on the contractual payments. The assessment of credit risk is conducted using two measures:

- $\quad$ probability of default;

- loss given default.

Here credit risk results from the risk of projects financed by debt instruments. Standard methods of the analysis of credit risk are very well developed in Polish banks. On the one hand, there are databases about borrowers (for example, the Credit Information Bureau). On the other hand, advanced statistical methods (including machine learning methods), estimate probabilities of default.

Bonds used to finance renewable energy projects are usually backed by the assets, which significantly reduces loss in the case of default. This means lower risk compared to the risk of loans. Credit risk can be managed using insurance or credit derivatives (the latter in the case of large investments in bonds).

This leads to the conclusion that the negative effects of credit risk are rather low.

Interest rate risk is reflected in two cases:

- fixed interest bond;

- $\quad$ floating interest bond.

For fixed interest bonds the negative effect of bond issuer risk occurs when the interest rates on the financial market are raising. This decreases the value of the bond-coupon payments are relatively low given market interest rates. Banks can manage this risk by buying a putable bond, which gives the bank right to sell the bond back before maturity. This right is then used when interest rates on the market are raising.

For floating interest bonds the negative effect of bond issuer risk occurs when the reference rate which determines coupon payments (e.g., LIBOR) is floating. The issuer can manage this risk by using derivative instruments, for example, forward rate agreement, floor, or interest rate swap.

Prepayment risk will occur when the interest rates fall. Then there is a need to invest additional cash flows coming from prepayment at lower interest rates. This type of risk is not high, it can be managed through the proper construction of a loan contract.

\subsubsection{Bank as an Investor on the Equity Market}

The bank can also invest in the equity market, investing in the shares of the companies conducting RES projects. In this case, the main risk is the market risk resulting from the changes of prices. This type of risk can be managed by the diversification of the investment portfolio and/or using equity derivatives.

\subsubsection{Bank as an Intermediary (Underwriter) and Organizer of the Issue}

The bank can be either investment underwriter or service underwriter. The investment underwriter buys this part of the issue, which was not sold on the primary market. The bank is here simply the investor. Therefore all the considerations about the risk presented earlier are valid. The service underwriter buys the whole issue from the issuer to sell it on the primary market. The bank becomes here "issuer" and there is the risk of nonplacement of the issue, discussed earlier.

The presented considerations were mainly related to the bank operating on the financial market. It led to the conclusion that risk is relatively low. However, there is also the risk that cash flows from renewable energy projects are lower than projected. Then, the bank should generate cash flows from other sources to make coupon payments.

Here are exemplary situations, in which these negative effects can occur: 
- The rejection, by the energy operator, of including the installation in the network (in Poland this refers to the installations above $50 \mathrm{~kW}$ );

- The low reliability of the installation (e.g., for heat pump).

We assess this risk as relatively low, given the professional feasibility analysis of renewable energy projects.

In addition to the mentioned risks, there is also risk resulting from the changes in the regulations. In the last few years, this risk has been observed in Poland as wind power stations are concerned. In the case of renewable energy projects, this risk is derived from the activities of political parties. In Poland, this risk will probably be decreased as the result of the need to comply with the Polish energy policy the EU regulations.

The presented analysis answers our third research question.

\subsection{Assessment of the Instruments Provided by Banks in Poland to Finance Renewable Energy Projects}

First, we identified the following potential financial instruments for renewable energy projects for the banking sector in Poland:

- loans and borrowings,

- investment loans,

- project finance,

- public-private partnership (PPP),

- leasing,

- green bonds,

- VC/PE funds,

- hybrid instruments.

Based on our findings and consultations with experts, theorists, and practitioners from the banking industry, we provide an expert assessment for each of the potential instruments that a bank can tackle in all three roles introduced in point 4.3.

Each of the instruments was assessed in the following criteria:

- risk-creditworthiness of the customer, credibility of the technology supplier;

- value of the capital engaged-the value of investment and value of financial instrument;

- profitability - the rate of return on the instrument;

- availability for the bank-easiness of organization of the process (repeatability vs. tailor-made);

- $\quad$ reputation-the image of the bank;

- support for energy transformation.

The points granted for each type of instrument and each criterium are on a scale between 1 and 3 , where 3 signifies the most favorable situation and 1, the least favorable. The assessment is done from the perspective of a bank.

Based on the results of the assessment, presented in Table 4, it can be stated that loans and credits granted to individuals and small enterprises as well as loans granted to large companies in the scope of PPP are characterized by the lowest risk. Project finance and PPP are the most capital intense. Bonds have been assessed as the most profitable, while loans and borrowings and leasing are the most repeatable. At the same time, leasing and bonds are least favorable from the perspective of reputation. Instruments that provide the best support for energy transformation are those of the biggest value-investment loans, project finance, and PPP. 
Table 4. Experts' assessment of the instruments provided by banks to finance renewable energy projects.

\begin{tabular}{|c|c|c|c|c|c|c|c|}
\hline \multirow[b]{2}{*}{$\begin{array}{l}\text { Type of the } \\
\text { Instrument }\end{array}$} & \multicolumn{6}{|c|}{ Criteria } & \multirow[b]{2}{*}{ Total } \\
\hline & Risk & $\begin{array}{l}\text { Value of the } \\
\text { Capital }\end{array}$ & Profitability & Availability & Reputation & $\begin{array}{c}\text { Energy Transformation } \\
\text { Support }\end{array}$ & \\
\hline $\begin{array}{l}\text { loans and } \\
\text { borrowings }\end{array}$ & 3 & 1 & 1 & 3 & 3 & 2 & 13 \\
\hline investment loans & 2 & 2 & 2 & 2 & 3 & 3 & 14 \\
\hline Bonds & 1 & 2 & 3 & 2 & 1 & 1 & 10 \\
\hline Green bonds & 2 & 2 & 2 & 2 & 3 & 2 & 13 \\
\hline Leasing & 2 & 1 & 1 & 3 & 1 & 1 & 9 \\
\hline Project finance & 2 & 3 & 2 & 1 & 3 & 3 & 14 \\
\hline PPP & 3 & 3 & 2 & 1 & 3 & 3 & 15 \\
\hline
\end{tabular}

Based on this assessment we created a ranking of financing instruments for renewable energy sources. The order of instruments is presented in Table 5.

Table 5. Ranking of the instruments.

\begin{tabular}{ccc}
\hline Ranking & Type of the Instrument & Total \\
\hline 1. & PPP & 15 \\
\hline 2. & Investment loans & 14 \\
\hline 2. & Project-finance & 14 \\
\hline 3. & Loans and borrowings & 13 \\
\hline 4. & Green bonds & 13 \\
\hline 5. & Bonds & 10 \\
\hline 6. & Leasing & 9 \\
\hline
\end{tabular}

Source: Own work.

The ranking shows that the most favorable financing instruments for renewable energy investments are public-private partnership (first), investment loans, and project finance (second place ex aequo with the same amount of points).

Based on these findings we answer our second research question.

\section{Conclusions and Discussion}

The analysis conducted in this paper is the basis for the recommendations concerning the financing of renewable energy projects by banks in Poland. The key recommendations are discussed in the following part of the paper.

- The general strategy of the European Commission on ecological financing concerns "investments and financing to complete the transition to the economy which is climateneutral". Therefore, the European Commission or European Parliament would seek ways to reflect climate risk in the bank capital in Poland or through supervisory actions in Pillar 2 or through supporting green investments in Pillar as the supplement to CRR3.

- The growth of the interest of banks in Polish market in different programs can be observed. At present, the financing of renewable energy projects is either through programs of NFOŚiGW and foreign financing or through preferential loans offered by banks. 
- It seems that different forms of financing renewable energy in Poland need to be combined, e.g., equity, credit, and liabilities. This recommendation refers to a one-off one-time return, e.g., by energy companies.

- Wind energy, as a source with a dominant share of power in all types of RES in Poland, requires special attention in the context of the functioning of all stakeholder groups: decision-makers, producers (of individual elements of wind turbines), investors, banks, and households.

- It is crucial to analyze the impact of wind energy on the natural environment and an information campaign on this subject among local communities, in the case of financing wind energy, the Polish banking sector should also have this type of analysis.

- The incumbent, insignificant number of offers of banks on the Polish market dedicated to financing RE investments are dominated by loans for financing photovoltaic installations (an increase in the share of the solar energy in the energy mix of Poland and internationally over the last few years can be noticed). The increase also results from the current system of subsidies for this type of investment in RES. It seems that this trend will be observed in the longer term. Therefore, it is recommended for the Polish banking industry to develop new products dedicated to this type of RES. A solution may also be to emphasize that a given bank product (e.g., a standard cash loan) can be used to finance photovoltaic or solar installations, and then the applicant will receive more preferential conditions than for a standard product (e.g., related to APRC).

- In the above context, the fact of receiving a subsidy for a part of the investment in the field of renewable energy investments (e.g., for the Mój Prąd program the subsidy amount of PLN 5000 only for a part of the investment) should be considered in the assessment of creditworthiness. If the applicant has received a grant, it means that he is environmentally conscious, has adequate income to pay off future loan obligations.

- It is recommended to banking sector in Poland enable the receipt of a loan from a RES device supplier (e.g., Paribas Bank). Such a simplification of the procedure could result in the greater interest of potential applicants who are usually discouraged by extended loan/credit procedures.

- In the case of bank loans we recommend transferring funds to an account indicated by the applicant (which does not have to be an account kept with the lender).

- We postulate an increase in the possibility of using leasing to finance investments in renewable energy in Poland. Currently, 5 leasing companies deal with the financing of photovoltaic installations, and two years ago, none of the companies wanted to finance this type of investment. Therefore, it seems justified to promote leasing for potential clients of financial institutions. An important issue in a photovoltaic (PV) installation is the interpretation of whether a given device should be treated as one that is permanently connected to the ground or not. If following the interpretation adopted by the bank, a given device can be treated as non-permanently connected to the ground, then it may be the subject of security in leasing financing.

- In the case of granting long-term loans related to RES financing, the credit risk should be carefully analyzed; the following proposed indicators may prove helpful:

(a) relation: the value of commission and interest income from loans for investments in renewable energy sources/total commission and interest income;

(b) relation: the percentage share of all outstanding and untimely repaid loans for RES investments in total loans/percentage share of all outstanding and untimely repaid loans in total loans.

- According to experts (Eriks Atvars, Managing Director-UniCredit Bank AG), the lender (primarily the bank) must have clarity, transparency, and regulatory certainty for investing in RES. Therefore, a general conclusion could be drawn to improve these aspects in the Polish banking sector. 
- When analyzing various forms of renewable energy financing in Poland, a lack of financing with hybrid instruments can be noticed; more attention should be paid to this type of product, e.g., mezzanine.

- Investments through VC/PE funds have played a minor role in recent years (almost $1 \%$ of the total invested funds on a global scale), therefore this form should also be more broadly considered and analyzed in the possibilities of financing investments in renewable energy.

- The instruments that support the energy transformation to the greatest extent are large investment loans, as well as project finance and PPP projects globally. Therefore, we recommend extending the introduction of those instruments on Polish grounds.

- The lowest risk is related to credits and loans (granted to individuals and small business entities) and loans granted to large entities as part of public-private partnership (PPP) projects. This leads to the conclusion that these types of instruments should be preferred by Polish banks.

- The analysis of banking risk related to investing in financial instruments which could be the source of financing of RES indicates that this type of risk is relatively low, therefore this type of bank involvement should be included in the policy recommendations.

Detailed recommendations for Poland resulting from the analysis of selected other countries are proposed in the following part of the paper. Based on the literature review and detailed analysis of renewable energy financing instruments used in selected countries that were provided by the authors in the report being a result of the project of Polish Bank Association: "Financing investments in renewable energy by Polish banks" [53] a set of recommendations for the Polish banking sector was prepared.

The first point of reference to derive recommendations for the Polish banking sector is the German market as the German economy is a specific benchmark for other countries in terms of the share of renewable energy in both electricity production, the share of RES in final consumption, as well as the scale of applications of devices using this type of energy. Germany may also be a benchmark for Poland in terms of financing renewable energy sources due to the following reasons: tight economic and trade relationship, similar topography and the high rate of economic development of the German economy.

Apart from Germany, the inspirations coming from Scandinavian countries, Australia, New Zealand, Italy, and Romania may be the most interesting for Poland.

In all these countries, apart from Romania, a significant trend is observed in the use of green bonds to finance projects related to investments in renewable energy. This is an important recommendation for the Polish market, as these instruments are used only to a marginal extent.

The first recommendation resulting from the example of Germany concerns the consistency of information on complementary support systems and sources of financing by institutions that manage these instruments.

In Germany, in most programs, if it is not possible to finance the missing amount with own equity, a given program allows obtaining the missing amount in the form of a preferential loan. The situation is different in the case of Poland, where, for example, for the Mój Prad program, the entire amount is not enough to finance a photovoltaic project, the beneficiary must take care of financing the remaining funds in the form of a credit or loan.

Other recommendations for the policymakers and the banking sector in Poland derived from the German banking sector include:

- The development of an up-to-date database of support programs, with information about banks and their location where the missing part of funding can be received in the form of a loan or credit. The following can be used as benchmarks: https:/ / www. deutschland-machts-effizient.de/KAENEF/Navigation/DE/Home/home.html (accessed on 13 August 2021). https://www.foerderdatenbank.de/FDB/DE/Home/ home.html (accessed on 13 August 2021). 
- Closer cooperation of financing institutions (including the National Fund for Environmental Protection and Water Management-NFOŚiGW) and the banking sector. https:// www.deutschland-machts-effizient.de/KAENEF/Navigation/DE/Home/home.html (accessed on 13 August 2021). https://www.foerderdatenbank.de/FDB/DE/Home/ home.html (accessed on 13 August 2021).

- Banks' offers for financing renewable energy should contain information with which support programs given financing may be combined.

- Applications for financing investments in RES should be submitted together with applications for granting a preferential loan.

- Based on the analysis of the system operating in Romania, we can recommend for the banks operating at the Polish market:

- Implementation of a settlement system for owners of roof-mounted photovoltaic power plants with a unit capacity of more than $3 \mathrm{~kW}$ and up to a maximum of $100 \mathrm{~kW}$, consisting in the sale of unused energy to energy companies at a rate set by the national regulator of the energy market.

Recommendations from the analysis of solutions used in the Scandinavian countries are:

- Increasing the use of green bonds.

- The creation of banks, which activities would be fully dedicated to financing green investments, such as the Nordic Investment Bank (NIB), which issues green bonds, and the Nordic Environment Finance Corporation (NEFCO).

Additionally, an interesting element of the banking system in Denmark, Finland, Norway, and Sweden are specialized municipal banks to finance municipal projects. The main feature of these banks is their ability to borrow on favorable terms as the highest-rated public institutions. They play an important role in green finance and have considerable expertise in this regard. They finance smaller green projects with less credible investors. Financing is done by loans or green bonds issues.

An example is Kommuninvest, which was established in the mid-1980s by several municipalities and county councils in central Sweden. Its purpose is to combine their borrowing needs and bypassing the banking sector by jointly borrowing in the international market. A key feature of the Kommuninvest structure is a joint and several guarantee agreements between members for all current and future Kommuninvest loans.

Such a role in Poland could be taken over by cooperative banks that operate closer to local communities and know their problems and needs. In the long term, an interesting solution would be to use the example of Scandinavian municipal banks.

The inspiration coming from the Australian market may be investment projects in renewable energy sources implemented by communities and partnerships of communities and developers operating in the form of cooperatives or joint-stock companies. These entities obtain financing from subsidies or social funding platforms. Similar solutions are available in the United Kingdom. Even though it is rather a recommendation related to the organization of the demand side, it is important since it can stimulate the launching of such partnerships using dedicated banking products.

There could also be some recommendations drawn based on the situation in Mediterranean countries, especially in Italy where key role in financing of renewable energy projects is taken by project-finance where banks play a major role. Minibonds could be another suggested solution that is commonly used to finance discussed projects run by small and medium private enterprises and start-ups. Project bonds issued in Italy could be an interesting solution for Polish big infrastructure renewable energy projects where banks, insurers, or financial intermediaries could be a guarantee providers.

By providing these recommendations we answer our first research question.

In conclusion, we argue that there are no limitations to the activities of the banking sector involved in renewable energy financing. Financing the present scale, scope, and the number of large renewable energy projects should not disrupt current liquidity in the Polish banking sector, given the possibility of creating banking consortia. 
With this paper we contribute to the existing literature in three ways. First, we provide a comprehensive analysis of existing solutions to finance renewable energy projects and we provide recommendations for banking sector in Poland. Second, we introduce an expert assessment to investigate the effectiveness of financial instruments used by banks for finance renewable energy sources and provide ranking of those instruments. Third, we provide insights about the types of risks faced by the banking sector considering all the roles the banks can play when it comes to financing of renewable energy sources.

\section{Limitations, Futures Studies and Directions}

As with any scientific paper, this one also has some limitations. The main one comes from the fact that the provided ranking of the instruments supporting renewable energy projects is based on expert opinions. This, of course, is sensitive to the choice of experts as well as using an ordinal scale for deriving ranking. The other limitation is due to the regulatory changes, which unfortunately take very often place in Poland. If they are significant, then an update of our results will be needed. The issue of the impact of regulatory changes on the shifts in the development and financing of renewable energy sources across countries could be an interesting field of future research.

In future studies, we want to concentrate on the analysis from the other stakeholders' perspectives as well as on the quantitative analysis for each of the sources of renewable energy. We might be able to develop an econometric model to research the most important factors influencing development of financing instruments for renewable energy sources.

Author Contributions: Conceptualization, K.D.-Ż. and K.J.; investigation, K.D.-Ż. and J.Z.; methodology, K.D.-Ż. and J.Z.; project administration, J.Z.; resources, J.Z.; supervision, K.D.-Ż. and K.J.; validation, K.D.-Ż.; writing-original draft, K.D.-Ż., K.J. and J.Z.; writing-review and editing, K.D.-Ż. and K.J. All authors have read and agreed to the published version of the manuscript.

Funding: The project is financed by the Ministry of Science and Higher Education in Poland under the program "Regional Initiative of Excellence" 2019-2022 project number 015/RID/2018/19 total funding amount 10721 040,00 PLN.

Conflicts of Interest: The authors declare no conflict of interest. The sponsors had no role in the design, execution, interpretation, or writing of the study.

\section{References}

1. Owusu, P.A.; Sarkodie, S.A. A review of renewable energy sources, sustainability issues and climate change mitigation. Cogent Eng. 2016, 3, 2-14. [CrossRef]

2. Matthäus, M.; Mehling, M. De-risking Renewable Energy Investments in Developing Countries: A Multilateral Guarantee Mechanism. Joule 2020, 4, 2627-2645. [CrossRef]

3. Szakály, Z.; Balogh, P.; Kontor, E.; Gabnai, Z.; Bai, A. Attitude toward and Awareness of Renewable Energy Sources: Hungarian Experience and Special Features. Energies 2021, 14, 22. [CrossRef]

4. Share of Renewables in Electricity Production. Available online: https://yearbook.enerdata.net/renewables/renewable-inelectricity-production-share.html (accessed on 13 August 2021).

5. Luthra, S.; Kumar, S.; Garg, D.; Haleem, A. Barriers to renewable/sustainable energy technologies adoption: Indian perspective. Renew. Sustain. Energy Rev. 2015, 41, 762-776. [CrossRef]

6. Martin, N.; Rice, J. Developing renewable energy supply in Queensland, Australia: A study of the barriers, targets, policies and actions. Renew. Energy 2012, 44, 119-127. [CrossRef]

7. Dincer, I. Renewable energy and sustainable development: A crucial review. Renew. Sustain. Energy Rev. 2000, 4, 157-175. [CrossRef]

8. Foxon, T.J.; Gross, R.; Chase, A.; Howes, J.; Arnall, A.; Anderson, D. UK innovation systems for new and renewable energy technologies: Drivers, barriers and systems failures. Energy Policy 2005, 33, 2123-2137. [CrossRef]

9. Fouquet, D.; Johansson, T. European renewable energy policy at crossroads-Focus on electricity support mechanisms. Energy Policy 2008, 36, 4079-4092. [CrossRef]

10. Steffen, B. The importance of project finance for renewable energy projects. Energy Econ. 2018, 69, 280-294. [CrossRef]

11. Polzin, F.; Sanders, M. How to finance the transition to low-carbon energy in Europe? Energy Policy 2020, 147, 111863. [CrossRef]

12. Lazaroiu, G.; Mihaescul, L.; Jarcu, E.A.; Stanescu, L.A.; Ciupageanu, D.A. Renewable energy employment in Romania: An environmental impact discussion. In Proceedings of the 20th International Multidisciplinary Scientific GeoConference SGEM 2020, Sofia, Bulgaria, 18-24 August 2020; Volume 20, pp. 177-184. [CrossRef] 
13. National Fund for Environmental Protection and Water Management. Available online: http://www.nfosigw.gov.pl/ofertafinansowania/ (accessed on 15 January 2020).

14. Ma, J.; Oppong, A.; Acheampong, K.N.; Abruquah, L.A. Forecasting Renewable Energy Consumption under Zero Assumptions. Sustainability 2018, 10, 576. [CrossRef]

15. Siemiattkowski, P.; Tomaszewski, P.; Marszałek-Kawa, J.; Gierszewski, J. The Financing of Renewable Energy Sources and the Level of Sustainable Development of Poland's Provinces in the Area of Environmental Order. Energies 2020, 13, 5591. [CrossRef]

16. European Parliament. European Commission Directive (EU) 2018/2001 of the European Parliament and of the Council of 11 December 2018 on the Promotion of the Use of Energy from Renewable Sources; European Parliament: Brussels, Belgium, 2018.

17. Ciupăgeanu, D.; Lăzăroiu, G.; Tîrşu, M. Carbon dioxide emissions reduction by renewable energy employment in Romania. In Proceedings of the 2017 International Conference on Electromechanical and Power Systems (SIELMEN), Iasi, Romania, 11-13 October 2017; pp. 281-285. [CrossRef]

18. Europe 2020-A Strategy for Smart, Sustainable and Inclusive Growth. Available online: https://eur-lex.europa.eu/legal-content/ EN/TXT/PDF/?uri=CELEX:52010DC2020\&from=EN (accessed on 13 August 2021).

19. European Commission. A European Green Deal. Available online: https://ec.europa.eu/info/strategy/priorities-2019-2024/ european-green-deal_pl (accessed on 20 June 2020).

20. European Commission. Clean energy. Available online: https://ec.europa.eu/commission/presscorner/detail/pl/fs_19_6723 (accessed on 22 June 2020).

21. Ministry of Climate and Environment. Energy policy of Poland until 2040. Available online: https://www.gov.pl/web/klimat/ polityka-energetyczna-polski (accessed on 13 August 2021).

22. Jajuga, K.; Zabawa, J.; Daszyńska-Żygadło, K. Report "Financing Investments in Renewable Energy by Polish Banks"; Programu Analityczno-Badawczego Fundacji Warszawski Instytut Bankowości; The Polish Bank Association: Warszawa, Poland, 2020.

23. Standar, A.; Kozera, A.; Satoła, Ł. The Importance of Local Investments Co-Financed by the European Union in the Field of Renewable Energy Sources in Rural Areas of Poland. Energies 2021, 14, 450. [CrossRef]

24. Zhang, F. Leaders and followers in finance mobilization for renewable energy in Germany and China. Environ. Innov. Soc. Transit. 2020, 37, 203-224. [CrossRef]

25. Geddes, A.; Schmidt, T.S.; Steffen, B. The multiple roles of state investment banks in low-carbon energy finance: An analysis of Australia, the UK and Germany. Energy Policy 2018, 115, 158-170. [CrossRef]

26. D'Orazio, P.; Löwenstein, P. Mobilising investments in renewable energy in Germany: Which role for public investment banks? J. Sustain. Financ. Invest. 2020, AHEAD-OF-PRINT. 1-24. [CrossRef]

27. Chen, X.; Gallagher, K.P.; Mauzerall, D.L. Chinese Overseas Development Financing of Electric Power Generation: A Comparative Analysis. One Earth 2020, 3, 491-503. [CrossRef]

28. Zhang, S. Innovative business models and financing mechanisms for distributed solar PV (DSPV) deployment in China. Energy Policy 2016, 95, 458-467. [CrossRef]

29. Niczyporuk, H.; Urpelainen, J. Taking a gamble: Chinese overseas energy finance and country risk. J. Clean. Prod. 2021, 281, 124993. [CrossRef]

30. He, L.; Liu, R.; Zhong, Z.; Wang, D.; Xia, Y. Can green financial development promote renewable energy investment efficiency? A consideration of bank credit. Renew. Energy 2019, 143, 974-984. [CrossRef]

31. Ponorîcă, A.G.; Zaqeer, L.J.; Al Saedi, A.H.J. Public funding for emerging countries. Qual. Access Success. 2015, 16, 7-11.

32. Steffen, B.; Schmidt, T.S. A quantitative analysis of 10 multilateral development banks' investment in conventional and renewable power-generation technologies from 2006 to 2015, 4. Nat. Energy 2019, 4, 75-82. [CrossRef]

33. Cabré, M.M.; Gallagher, K.P.; Li, Z. Renewable Energy: The Trillion Dollar Opportunity for Chinese Overseas Investment. China World Econ. 2018, 26, 27-49. [CrossRef]

34. Hochstetler, K.; Kostka, G. Wind and Solar Power in Brazil and China: Interests, State-Business Relations, and Policy Outcomes. Glob. Environ. Politics 2015, 15, 74-94. [CrossRef]

35. Oliveira, L.G.; Aquila, G.; Balestrassi, P.P.; Paiva, A.P.; de Queiroz, A.R.; de Oliveira Pamplona, E.; Camattaca, U.P. Evaluating economic feasibility and maximization of social welfare of photovoltaic projects developed for the Brazilian northeastern coast: An attribute agreement analysis. Renew. Sustain. Energy Rev. 2020, 123, 109786. [CrossRef]

36. Lara, M.O.D.; Unsihuay-Vila, C.; Silva, V.R.G.R.D. Technical and economic viability of the installation of a hybrid solar-wind generation system in a Brazilian industry. Braz. Arch. Biol. Technol. 2019, 62, e19190005. [CrossRef]

37. Proctor, D. Kazakhstan Adds New Solar Plant to Growing Renewables Capacity. 2019. Available online: https://www.powermag. com/kazakhstan-adds-new-solar-plant-to-growing-renewables-capacity/ (accessed on 13 May 2021).

38. Amesho, K.T.T.; Edoun, E.I. Financing Renewable Energy in Namibia-A Fundamental Key Challenge to the Sustainable Development Goal 7: Ensuring Access to Affordable, Reliable, Sustainable and Modern Energy for All. Int. J. Energy Econ. Policy 2019, 9, 442-450. [CrossRef]

39. Kalirajan, K.; Chen, H. Private Financing in Low-Carbon Energy Transition: Imbalances and Determinants. In Financing for Low-carbon Energy Transition; Anbumozhi, V., Kalirajan, K., Kimura, F., Eds.; Springer: Singapore, 2018. [CrossRef]

40. Albertario, P. System of self-financing strategy for the policies aimed at the eco-innovation in the productive sectors, Procedia Environmental Science. Eng. Manag. 2016, 3, 1-6. 
41. Panteli, C.; Klumbytè, E.; Apanavičienè, R.; Fokaides, P.A. An Overview of the Existing Schemes and Research Trends in Financing the Energy Upgrade of Buildings in Europe. J. Sustain. Archit. Civil. Eng. 2020, 27, 53-62. [CrossRef]

42. Zabawa, J. Bankowość Ekologiczna w Społecznej Odpowiedzialności Biznesu. Rola, Uwarunkowania i Mierniki; Wydawnictwo UE we Wrocławiu: Wrocław, Poland, 2019.

43. Zabawa, J.; Kozyra, C. Eco-Banking in Relation to Financial Performance of the Sector-The Evidence from Poland. Sustainability 2020, 12, 2162. [CrossRef]

44. Masud, M.A.K.; Bae, S.M.; Kim, J.D. Analysis of Environmental Accounting and Reporting Practices of Listed Banking Companies in Bangladesh. Sustainability 2017, 9, 1717. [CrossRef]

45. Garcia-Bernabeu, A.; Mayor-Vitoria, F.; Bravo, M.; Pla-Santamaria, D. Financial risk management in renewable energy projects: A multicriteria approach. J. Manag. Inf. Decis. Sci. 2019, 22, 360-371.

46. Lowitzsch, J. Consumer Stock Ownership Plans (CSOPs)-The Prototype Business Model for Renewable Energy Communities. Energies 2020, 13, 118. [CrossRef]

47. McInerney, C.; Bunn, D.W. Expansion of the investor base for the energy transition. Energy Policy 2019, 129, 1240-1244. [CrossRef]

48. Frisari, G.; Stadelmann, M. De-risking concentrated solar power in emerging markets: The role of policies and international finance institutions. Energy Policy 2015, 82, 12-22. [CrossRef]

49. Sukirman, Y.A. Developing a green lending model for renewable energy project (case study electricity from biogas fuel at Palm Oil Industry). IOP Conf. Ser. Earth Environ. Sci. 2018, 131, 012037. [CrossRef]

50. Mazzucato, M.; Semieniuk, G. Financing renewable energy: Who is financing what and why it matters. Technol. Forecast. Soc. Chang. 2018, 127, 8-22. [CrossRef]

51. Safarzyńska, K.; van den Bergh, J.C.J.M. Financial stability at risk due to investing rapidly in renewable energy. Energy Policy 2017, 108, 12-20. [CrossRef]

52. Bukowski, M.; Marszał, K.; Micuła, P.; Śniegocki, A.; Wetmańska, Z.; Zmienny, P. Panorama Niskoemisyjnych Inwestycji w Energetyce; WiseEuropa: Warszawa, Poland, 2020.

53. Scenariusz Polityki Energetyczno-Klimatycznej (PEK). Available online: https://www.google.com/url?sa=t\&rct=j\&q=\&esrc= s\&source=web\&cd=\&ved=2ahUKEwic-ZOLtrDzAhVggv0HHWHeCI0QFnoECAYQAQ\&url=https\%3A\%2F\%2Fwww.gov.pl\% 2Fattachment\%2Fa8db078d-535b-4b1b-bfe5-bda64df73778\&usg=AOvVaw1Nhw_rdv51Zj_KoGuSX_pO (accessed on 25 May 2021). 